Article

\title{
Comparison of Herbicides for Control of Diclofop-Resistant Italian Ryegrass in Wheat
}

\author{
Taghi Bararpour ${ }^{1, *}$, Ralph R. Hale ${ }^{1}$, Gurpreet Kaur ${ }^{1}{ }^{10}$, Jason A. Bond ${ }^{1}$, Nilda R. Burgos ${ }^{2}$, \\ Te-Ming P. Tseng ${ }^{3}{ }^{(B)}$, Tessie H. Wilkerson ${ }^{1}$ and Lauren M. Lazaro ${ }^{4}$ (i) \\ 1 Delta Research and Extension Center, Mississippi State University, 82 Stoneville Road, Stoneville, MS 38776, \\ USA; rrh187@msstate.edu (R.R.H.); GK340@msstate.edu (G.K.); JBond@drec.msstate.edu (J.A.B.); \\ twilkerson@drec.msstate.edu (T.H.W.) \\ 2 Department of Crop, Soil and Environmental Sciences, University of Arkansas, 1366 West Altheimer Drive, \\ Fayetteville, AR 72704, USA; nburgos@uark.edu \\ 3 Department of Plant and Soil Sciences, Mississippi State University, 316 Dorman Hall, Mississippi State, \\ MS 39762, USA; tt1024@msstate.edu \\ 4 Louisiana State University AgCenter, 109 Sturgis Hall, Baton Rouge, LA 70803, USA; \\ LLazaro@agcenter.lsu.edu \\ * Correspondence: mtb436@msstate.edu; Tel.: +1-662-686-3232; Fax: +1-662-686-7336
}

Received: 31 July 2018; Accepted: 24 August 2018; Published: 1 September 2018

\begin{abstract}
Diclofop-resistant Italian ryegrass (Lolium perenne L. ssp. Multiflorum (Lam.) Husnot) is a dominant weed problem in non-irrigated winter wheat (Triticum aestivum L.) in mid-south USA. Field studies were conducted from 2001 to 2007 to evaluate the efficacy of herbicides for diclofop-resistant ryegrass control and effect on wheat yield. In 2001 through 2004, chlorsulfuron/metsulfuron at $0.026 \mathrm{~kg} \mathrm{ha}^{-1}$ preemergence (PRE) followed by (fb) mesosulfuron at $0.048 \mathrm{~kg} \mathrm{ha}^{-1}$ at 4-leaf to 2-tiller ryegrass provided $89 \%$ control of diclofop-resistant Italian ryegrass, resulting in the highest wheat yield (3201 $\mathrm{kg} \mathrm{ha}^{-1}$ ). Flufenacet/metribuzin at $0.476 \mathrm{~kg} \mathrm{ha}^{-1}$ applied at 1- to 2-leaf wheat had equivalent Italian ryegrass control $(87 \%)$, but lesser yield (3013 kg ha ${ }^{-1}$ ). In 2005-2006, best treatments for Italian ryegrass control were chlorsulfuron/metsulfuron, $0.013 \mathrm{~kg} \mathrm{ha}^{-1}$ PRE fb mesosulfuron $0.015 \mathrm{~kg} \mathrm{ha}^{-1}$ at 3- to 4-leaf ryegrass (92\%); metribuzin, $0.280 \mathrm{~kg} \mathrm{ha}^{-1}$ at 2- to 3- leaf wheat fb metribuzin at 2- to 3-tiller ryegrass (94\%); chlorsulfuron/metsulfuron $\left(0.026 \mathrm{~kg} \mathrm{ha}^{-1}\right)(89 \%)$; and flufenacet/metribuzin at 1- to 2-leaf wheat $(89 \%)$. Chlorsulfuron/metsulfuron fb mesosulfuron provided higher yield $\left(3515 \mathrm{~kg} \mathrm{ha}^{-1}\right)$ than all other treatments, except metribuzin fb metribuzin.
\end{abstract}

Keywords: flufenacet; metribuzin; chlorsulfuron; mesosulfuron; metsulfuron

\section{Introduction}

Herbicide-resistant (HR) weeds have been a prominent issue in commercial crop production for many years. The number of HR weeds has increased drastically since herbicides were commercialized for in-crop usage, possibly due to overreliance on herbicides, a low-dose selection from herbicide drift, incorrect application rates and timing [1], and persistent selection pressure across vast croplands. Currently, 471 weed species have been identified and documented as herbicide-resistant, making chemical weed control challenging in multiple cropping systems [2]. In Arkansas, USA, Italian ryegrass (Lolium perenne L. ssp. multiflorum) is one of the most common and problematic weed species in winter wheat (Triticum aestivum L.) [3,4]. Italian ryegrass is one of the 10 most troublesome weeds in wheat in ten of the 13 southern states of the USA [5]. Italian ryegrass has evolved resistance to three herbicide modes of action: acetyl-CoA carboxylase (ACCase) inhibitors, acetolactate synthesis (ALS) 
inhibitors, and 5-enolpyruvyl-shikimate-3-phosphate synthase (EPSPS) inhibitors in Arkansas [2]. ACCase-inhibiting herbicides are most commonly used for Italian ryegrass control. There are three chemical families in the ACCase-inhibiting herbicide group—the aryloxyphenoxypropionates (AOPP), cyclohexanediones (CHD), and phenylpyrazolins (PPZ).

Diclofop is an ACCase-inhibiting herbicide which is used for postemergence control of Italian ryegrass in wheat [6]. After years of repeated use, the first case of diclofop-resistant Italian ryegrass in the United States was reported in Oregon in 1987 [7-9]. Diclofop-resistant Italian ryegrass is the most problematic issue in wheat in Arkansas. Previous studies have reported that 10 Italian ryegrass plants $\mathrm{m}^{-2}$ reduced wheat yield by $4 \%$ [10], whereas wheat yield was reduced by $61 \%$ with 93 Italian ryegrass plants $\mathrm{m}^{-2}$ [11]. This high level of infestation is common in wheat fields.

Italian ryegrass can be controlled by alternating different herbicide modes of action. For example, Grey and Bridges [12] reported $>80 \%$ control of Italian ryegrass at $151 \mathrm{~d}$ after planting with metribuzin, metribuzin + flufenacet, chlorsulfuron, or chlorsulfuron + metsulfuron. Recently, an ACCase-inhibiting herbicide in the PPZ family, pinoxaden (Axial ${ }^{\circledR}$ ), has been used to control diclofop-resistant Italian ryegrass [13]. In a three-year study, Bararpour et al. [14] reported that pinoxaden applied to 1- to 2-tiller diclofop-resistant Italian ryegrass provided 65 to $68 \%$ and 45 to $49 \%$ control, at four and seven months after application, respectively. Although pinoxaden and diclofop have the same mode of action, pinoxaden binds differently to the catalytic site due to its significantly different chemical structure $[15,16]$. Hence, it is generally effective on diclofop-resistant Italian ryegrass. However, relying on pinoxaden to control diclofop-resistant Italian ryegrass may select for cross-resistance. Wheat producers can prolong the life of pinoxaden by using other herbicide modes of action on diclofop-resistant Italian ryegrass populations such as ALS- and microtubule assembly (MTA)-inhibiting herbicides. ALS-inhibiting herbicides such as mesosulfuron can control diclofop-resistant Italian ryegrass populations [17]. In addition to ALS-inhibiting herbicides, MTA-inhibiting herbicides such as pendimethalin, or very long chain fatty acid inhibitors such as pyroxasulfone can be used prior to a foliar herbicide application to increase control of Italian ryegrass in wheat [18-20]. Bararpour and Oliver [21] conducted a seven-year (2001-2007) study comparing wheat herbicides for diclofop-resistant Italian ryegrass and found that chlorsulfuron + metsulfuron (Finesse) followed by ( $\mathrm{fb}$ ) mesosulfuron (Osprey) was the best herbicide combination ( $96 \%$ control) in four years of study. However, metribuzin (Sencor) fb metribuzin provided $94 \%$ control in two years of study. In 2007, the greatest control (97\%) was attained with flufenacet + metribuzin (Axiom) on seedling Italian ryegrass. Chlorsulfuron + metribuzin or a split application of metribuzin, and flufenacet + metribuzin can control diclofop-resistant Italian ryegrass. The ALS-inhibitor, mesosulfuron, provided 55 to $68 \%$ and 73 to $74 \%$ control of diclofop-resistant Italian ryegrass at four and seven months after application, respectively [14]. Mesosulfuron alone provided 24\% higher control of diclofop-resistant Italian ryegrass than pinoxaden alone. Pinoxaden alone was not the best herbicide for diclofop-resistant Italian ryegrass. If pinoxaden is used, it will need to be split-applied and mixed with another herbicide such as metribuzin or flufenacet + metribuzin to control diclofop-resistant Italian ryegrass throughout the growing season [14].

Thus, diclofop-resistant Italian ryegrass in wheat cropping systems can be effectively controlled with the use of herbicides with different modes of action in each season. Relying on a single mode of action, such as an ACCase-inhibiting herbicide, can select for cross-resistance in diclofop-resistant Italian ryegrass. Therefore, the objective of our study was to evaluate the efficacy of herbicides available to Arkansas producers for control of diclofop-resistant Italian ryegrass in non-irrigated winter wheat.

\section{Materials and Methods}

Field studies were conducted for six years from 2001 to 2007 at the Agricultural Research and Extension Center in Fayetteville, Arkansas. The research was conducted on a silt loam soil with 21\% sand, $70 \%$ silt, $9 \%$ clay, $0.5 \%$ organic matter, and a pH of 5.8 . Wheat was planted in October- November and harvested in June or July (Table 1). Wheat cultivar Pioneer 2684 and Beretta 989 were used in 
2001-2005 and 2006-2007, respectively. Wheat seeding rate was $112 \mathrm{~kg} \mathrm{ha}^{-1}$ and row spacing was $18 \mathrm{~cm}$. Wheat plots were fertilized with $23 \mathrm{~kg} \mathrm{P} \mathrm{ha}^{-1}$ and $56 \mathrm{~kg} \mathrm{~K} \mathrm{ha}^{-1}$ prior to planting in October. The wheat plots also received $112 \mathrm{~kg} \mathrm{~N} \mathrm{ha}^{-1}$ in early March.

Table 1. Wheat planting, emergence, and harvesting date from 2001 to 2007.

\begin{tabular}{cccc}
\hline Year & Planting & Emergence & Harvest \\
\hline $2001-2002$ & 22-October & 1-November & 20-June \\
$2002-2003$ & 23-October & 2-November & 16-June \\
$2003-2004$ & 20-October & 25-October & 18-June \\
$2004-2005$ & 21-October & 26-October & 28-June \\
$2005-2006$ & 28-October & 5-November & 7-June \\
$2006-2007$ & 24-October & 3-November & 25-June \\
\hline
\end{tabular}

The experiment was designed as a randomized complete block design with four replications. The research plot contained a uniform, natural infestation $\left( \pm 323\right.$ plants $\left.\mathrm{m}^{-2}\right)$ of diclofop-resistant Italian ryegrass. The plot size was $6 \mathrm{~m} \times 2 \mathrm{~m}$. The herbicide treatments, their trade names and manufacturer information are listed in Table 2. The herbicide treatments, their application rate, and timing information are provided in Table 3. The PRE herbicide applications were applied at the time of wheat planting. $\mathrm{A} \mathrm{CO}_{2}$-pressurized backpack sprayer with four 8002 flat-fan nozzles (TeeJet Technologies, Springfield, IL, USA) mounted on a handheld boom calibrated to deliver $187 \mathrm{~L} \mathrm{ha}^{-1}$ at $276 \mathrm{kPa}$ was used. A non-treated control was also included to evaluate the effects of different herbicide treatments on wheat yield. Glyphosate at $0.84 \mathrm{~kg}$ ae ha ${ }^{-1}$ was broadcast-applied to the entire experimental area immediately after planting to burn down undesirable vegetation.

Italian ryegrass control and wheat yield were measured. Crop injury and weed control were scored on a scale of 0-100 ( 0 being no injury or weed control and 100 being complete crop death or weed control). The visual rating for weed control or crop injury were made based on the whole plot area in comparison to the non-treated control plot. Wheat yield was adjusted to $12 \%$ moisture content. No yield data was collected in 2007 due to frost and stripe rust (Puccinia striiformis) damage to wheat. Data from 2001 through 2004 and from 2005 through 2006 were analyzed separately because different herbicide treatments were used. Monthly total rainfall and average temperature data for Fayetteville, AR from 2001 to 2007 was obtained from National Weather Service-National Oceanic and Atmospheric Administration (NOAA) website [22] (https: / /www.weather.gov/tsa/climo_fyv_ pcp_month). The Italian ryegrass control data from 2007 were analyzed separately because of the unusual weather event in that year. Data were analyzed by SAS Statistical Software v 9.3 using PROC GLM procedure. Means were separated using Fisher's Protected Least Significant Difference (LSD) at the $p<0.05$ probability level. Our initial analysis showed no interactions between the years and treatments and therefore, data were pooled over years. 
Table 2. Herbicide treatments, their trade names, and manufacturers, used in this study from 2001 to 2007.

\begin{tabular}{|c|c|c|c|}
\hline Year & Herbicide Treatments (Common Names) & Trade Name & Manufacturer \\
\hline \multirow[t]{6}{*}{ 2001-2004 } & Flufenacet/metribuzin & Axiom & Bayer CropScience, Research Triangle Park, North Carolina, USA \\
\hline & Chlorsulfuron/metsulfuron & Finesse & DuPont, Wilmington, Delaware, USA \\
\hline & Chlorsulfuron/metsulfuron $\mathrm{fb}^{\dagger}$ Mesosulfuron $+\mathrm{MSO}$ & Finesse fb Osprey & Dupont; Bayer CropScience \\
\hline & Mesosulfuron + UAN $\ddagger$ & Osprey & Bayer CropScience, Research Triangle Park, North Carolina, USA \\
\hline & Mesosulfuron $+\mathrm{MSO}^{+\dagger}+\mathrm{UAN}$ & Osprey & Bayer CropScience, Research Triangle Park, North Carolina, USA \\
\hline & Metribuzin fb Metribuzin & Sencor fb Sencor & Bayer CropScience, Research Triangle Park, North Carolina, USA \\
\hline \multirow[t]{6}{*}{ 2005-2007 } & Flufenacet/Metribuzin & Axiom & Bayer CropScience, Research Triangle Park, North Carolina, USA \\
\hline & Chlorsulfuron/Metsulfuron & Finesse & DuPont, Wilmington, Delaware, USA \\
\hline & Chlorsulfuron/Metsulfuron fb Mesosulfuron & Finesse fb Osprey & Dupont; Bayer CropScience \\
\hline & Mesosulfuron & Osprey & Bayer CropScience, Research Triangle Park, North Carolina, USA \\
\hline & Mesosulfuron fb Mesosulfuron & Osprey fb Osprey & Bayer CropScience, Research Triangle Park, North Carolina, USA \\
\hline & Metribuzin fb Metribuzin & Sencor fb Sencor & Bayer CropScience, Research Triangle Park, North Carolina, USA \\
\hline
\end{tabular}

Table 3. Herbicide treatments, their application rate and application timing used in this study from 2001 to 2007.

\begin{tabular}{|c|c|c|c|}
\hline Year & Herbicide Treatments & Application Rate (kg ai ha ${ }^{-1}$ ) & Application Timing \\
\hline \multirow[t]{6}{*}{ 2001-2004 } & Flufenacet/metribuzin & 0.476 & 1-2 leaf stage wheat \\
\hline & Chlorsulfuron/metsulfuron & 0.026 & $\mathrm{PRE}^{\dagger}$ \\
\hline & Chlorsulfuron/metsulfuron $\mathrm{fb}^{\dagger}$ Mesosulfuron $+\mathrm{MSO}$ & $0.026 \mathrm{fb} 0.048$ & PRE; 3-4 leaf ryegrass \\
\hline & Mesosulfuron + UAN $\ddagger$ & 0.048 & 1 - to 2 -tiller ryegrass \\
\hline & Mesosulfuron $+\mathrm{MSO}^{++}+\mathrm{UAN}$ & 0.048 & 1- to 2-tiller ryegrass \\
\hline & Metribuzin fb Metribuzin & $0.280 \mathrm{fb} 0.280$ & 2-3 leaf stage wheat; $2-3$ tiller wheat \\
\hline \multirow{6}{*}{ 2005-2007 } & Flufenacet/Metribuzin & 0.476 & $1-2$ leaf stage wheat \\
\hline & Chlorsulfuron/Metsulfuron & 0.026 & PRE \\
\hline & Chlorsulfuron/Metsulfuron fb Mesosulfuron & $0.013 \mathrm{fb} 0.015$ & PRE; 3-4 leaf ryegrass \\
\hline & Mesosulfuron & 0.015 & 1- to 2-tiller ryegrass \\
\hline & Mesosulfuron fb Mesosulfuron & $0.008 \mathrm{fb} 0.008$ & 1-2-tiller ryegrass; 4 -leaf to 2 -tiller ryegrass \\
\hline & Metribuzin fb Metribuzin & $0.280 \mathrm{fb} 0.280$ & 2-3 leaf stage wheat; $2-3$ tiller stage wheat \\
\hline
\end{tabular}




\section{Results}

\subsection{Weather Conditions during the Growing Seasons}

The total annual rainfall during the years 2003, 2005, and 2007 was less than $1000 \mathrm{~mm}$ (Table 4). All other years had total annual rainfall of more than $1000 \mathrm{~mm}$. The average annual temperature at the study site ranged from $13.7^{\circ} \mathrm{C}$ to $15.1^{\circ} \mathrm{C}$.

\subsection{1 through 2004}

There was no wheat injury from any herbicide application. Mesosulfuron + UAN (65\%) and Chlorsulfuron/metsulfuron (58\%) had significantly lower Italian ryegrass control than all other herbicide treatments (82 to $89 \%$ ) (Table 5). The highest control $(89 \%)$ was attained with chlorsulfuron/metsulfuron followed by $(\mathrm{fb})$ mesosulfuron $+\mathrm{MSO}$, which resulted in the highest wheat yield (3201 kg ha ${ }^{-1}$ ) compared to other treatments. The addition of MSO to mesosulfuron + UAN increased Italian ryegrass control by $20 \%$ compared to mesosulfuron+UAN (85 vs. 65\%). Metribuzin $\left(0.28 \mathrm{~kg} \mathrm{ha}^{-1}\right)$ at 2- to 3- leaf wheat fb metribuzin at 2- to 3-tiller wheat; flufenacet/metribuzin $\left(0.476 \mathrm{~kg} \mathrm{ha}^{-1}\right)$ at 1 - to 2-leaf wheat and mesosulfuron + MSO + UAN had similar ryegrass control as with chlorsulfuron/metsulfuron $\mathrm{fb}$ mesosulfuron + MSO. However, the wheat yields from mesosulfuron + MSO + UAN and metribuzin fb metribuzin were 439 and $565 \mathrm{~kg} \mathrm{ha}^{-1}$ lower than that of chlorsulfuron/metsulfuron fb mesosulfuron + MSO, respectively (Figure 1). Higher control of Italian ryegrass with mesosulfuron $+\mathrm{MSO}+\mathrm{UAN}$ and metribuzin $\mathrm{fb}$ metribuzin did not increase wheat yield relative to mesosulfuron + UAN or chlorsulfuron/metsulfuron. All herbicide treatments resulted in higher wheat yield compared to the non-treated control (Figure 1). The natural infestation of diclofop-resistant Italian ryegrass in this location reduced wheat yield $77 \%$ as compared to the highest yielding treatment.

\subsection{5 and 2006}

There was no wheat injury from any herbicide application. The best Italian ryegrass control was observed with metribuzin fb metribuzin (94\%), which was comparable to the control with chlorsulfuron/metsulfuron (PRE) fb mesosulfuron at 3- to 4-leaf ryegrass, chlorsulfuron/metsulfuron; and flufenacet/metribuzin at 1- to 2-leaf wheat (Table 5). Significantly lower control of Italian ryegrass was provided by the mesosulfuron $\mathrm{fb}$ mesosulfuron $\left(0.008 \mathrm{~kg} \mathrm{ha}^{-1}\right)(81 \%)$ and mesosulfuron $\left(0.015 \mathrm{~kg} \mathrm{ha}^{-1}\right)(86 \%)$ which resulted in reduced wheat yields as compared to metribuzin fb metribuzin and chlorsulfuron/metsulfuron fb mesosulfuron. The highest wheat yield was obtained from chlorsulfuron/metsulfuron fb mesosulfuron; metribuzin fb metribuzin ranked second (Figure 2). Wheat yield from chlorsulfuron/metsulfuron fb mesosulfuron was 502, 502, 1004, 1036 and $2197 \mathrm{~kg} \mathrm{ha}{ }^{-1}$ higher than the flufenacet/metribuzin, chlorsulfuron/metsulfuron, mesosulfuron $\left(0.015 \mathrm{~kg} \mathrm{ha}^{-1}\right)$, mesosulfuron $\mathrm{fb}$ mesosulfuron $\left(0.008 \mathrm{~kg} \mathrm{ha}^{-1}\right)$ and non-treated control, respectively. The natural infestation of diclofop-resistant Italian ryegrass at this location in these years reduced wheat yield $63 \%$ as compared to the highest yielding treatment (chlorsulfuron/metsulfuron fb mesosulfuron).

\subsection{7}

Control of diclofop-resistant Italian ryegrass was best with flufenacet/metribuzin (97\%) and chlorsulfuron/metsulfuron fb mesosulfuron (93\%) (Figure 3). The control of Italian ryegrass did not differ between mesosulfuron, mesosulfuron $\mathrm{fb}$ mesosulfuron, metribuzin fb metribuzin and chlorsulfuron/metsulfuron treatments. 
Table 4. Monthly total rainfall and average temperature at Fayetteville, AR from 2001 to 2007.

\begin{tabular}{|c|c|c|c|c|c|c|c|c|c|c|c|c|c|}
\hline Year & January & February & March & April & May & June & July & August & September & October & November & December & Annual Total/Average \\
\hline \multicolumn{14}{|c|}{ Monthly Total Rainfall (mm) } \\
\hline 2001 & 61 & 162 & 15 & 45 & 179 & 131 & 73 & 34 & 138 & 156 & 95 & 123 & 1213 \\
\hline 2002 & 91 & 25 & 141 & 155 & 126 & 89 & 53 & 168 & 35 & 67 & 18 & 127 & 1095 \\
\hline 2003 & 3 & 74 & 54 & 35 & 201 & 99 & 56 & 94 & 76 & 92 & 108 & 77 & 972 \\
\hline 2004 & 50 & 30 & 74 & 287 & 57 & 185 & 201 & 17 & 14 & 140 & 153 & 30 & 1239 \\
\hline 2005 & 141 & 52 & 49 & 92 & 85 & 112 & 36 & 42 & 92 & 46 & 27 & 10 & 783 \\
\hline 2006 & 45 & 17 & 92 & 103 & 97 & 52 & 41 & 189 & 183 & 82 & 184 & 52 & 1137 \\
\hline 2007 & 117 & 52 & 18 & 80 & 113 & 107 & 80 & 65 & 66 & 118 & 9 & 65 & 890 \\
\hline \multicolumn{14}{|c|}{ Monthly Average Temperature $\left({ }^{\circ} \mathrm{C}\right)$} \\
\hline 2001 & 0.7 & 5.4 & 6.5 & 16.8 & 18.4 & 22.3 & 26.4 & 25.8 & 19.4 & 13.5 & 11.4 & 4.6 & 14.3 \\
\hline 2002 & 3.2 & 3.5 & 7.3 & 15.2 & 17.7 & 22.8 & 25.4 & 24.8 & 21.5 & 12.9 & 6.6 & 3.9 & 13.7 \\
\hline 2003 & 0.9 & 2.3 & 8.8 & 14.3 & 18.5 & 20.9 & 25.4 & 26.0 & 18.7 & 15.1 & 10.1 & 4.2 & 13.8 \\
\hline 2004 & 2.7 & 3.1 & 10.5 & 14.2 & 19.4 & 22.1 & 23.4 & 22.2 & 20.6 & 16.6 & 10.6 & 3.9 & 14.1 \\
\hline 2005 & 5.3 & 6.7 & 7.8 & 13.7 & 17.7 & 23.5 & 25.3 & 26.6 & 23.4 & 15.1 & 10.2 & 2.4 & 14.8 \\
\hline 2006 & 7.2 & 3.5 & 10.2 & 17.5 & 19.3 & 22.5 & 26.6 & 27.3 & 18.7 & 13.7 & 9.2 & 5.4 & 15.1 \\
\hline 2007 & 1.2 & 3.3 & 13.4 & 11.7 & 19.7 & 23.0 & 24.4 & 27.1 & 21.7 & 16.5 & 9.6 & 4.3 & 14.7 \\
\hline
\end{tabular}

Table 5. Italian ryegrass control as affected by herbicide treatments used from 2001 to 2006.

\begin{tabular}{|c|c|c|c|}
\hline Year & Herbicide Treatments & Application Rate & Italian Ryegrass Control ${ }^{\ddagger}$ \\
\hline \multirow{7}{*}{ 2001-2004 } & & $\mathrm{kg}$ ai ha ${ }^{-1}$ & $\%$ \\
\hline & Flufenacet/metribuzin & 0.476 & 87 a \\
\hline & Chlorsulfuron/metsulfuron & 0.026 & $58 \mathrm{~b}$ \\
\hline & Chlorsulfuron/metsulfuron $\mathrm{fb}^{+}$Mesosulfuron $+\mathrm{MSO}^{+}$ & $0.026 \mathrm{fb} 0.048$ & 89 a \\
\hline & Mesosulfuron + UAN \& & 0.048 & $65 \mathrm{~b}$ \\
\hline & Mesosulfuron $+\mathrm{MSO}^{\S}+\mathrm{UAN}$ & 0.048 & 85 a \\
\hline & Metribuzin fb Metribuzin & $0.280 \mathrm{fb} 0.280$ & 82 a \\
\hline \multirow[t]{6}{*}{$2005-2006$} & Flufenacet/Metribuzin & 0.476 & $89 \mathrm{abc}$ \\
\hline & Chlorsulfuron/Metsulfuron & 0.026 & $89 \mathrm{abc}$ \\
\hline & Chlorsulfuron/Metsulfuron fb Mesosulfuron & $0.013 \mathrm{fb} 0.015$ & $92 \mathrm{ab}$ \\
\hline & Mesosulfuron & 0.015 & $86 \mathrm{bc}$ \\
\hline & Mesosulfuron fb Mesosulfuron & $0.008 \mathrm{fb} 0.008$ & $81 \mathrm{c}$ \\
\hline & Metribuzin fb Metribuzin & $0.280 \mathrm{fb} 0.280$ & $94 \mathrm{a}$ \\
\hline
\end{tabular}

${ }^{+} \mathrm{fb}$ means followed by; $\bar{\S}$ MSO is methylated seed oil applied at $1 \% \mathrm{v} / \mathrm{v} ;{ }^{\S}$ UAN (Urea Ammonium Nitrate) is fertilizer additive applied at $1.25 \% \mathrm{v} / \mathrm{v} ;{ }^{\ddagger}$ Values in the same column followed by the similar letter are not statistically different at $p \leq 0.05$. Means were compared separately for 2001-2004 and 2005-2006 data. 


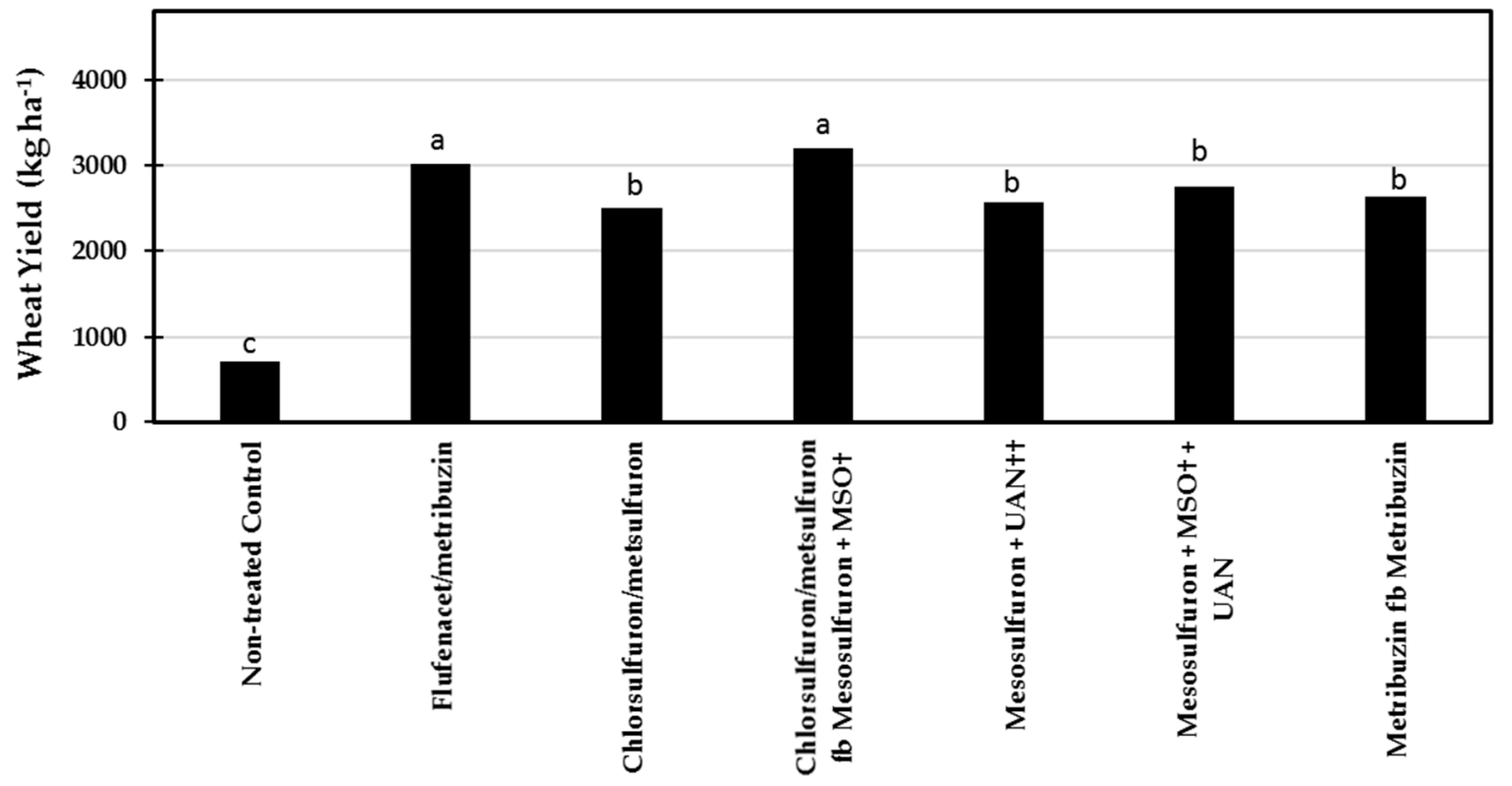

Figure 1. Wheat yield as affected by herbicide treatments used from 2001 to 2004 . MSO is methylated seed oil applied at $1 \% \mathrm{v} / \mathrm{v}$. UAN (Urea Ammonium Nitrate) is a fertilizer additive applied at $1.25 \%$ $\mathrm{v} / \mathrm{v}$. fb means followed by. A similar letter on bars indicate no statistical difference at $p \leq 0.05$.

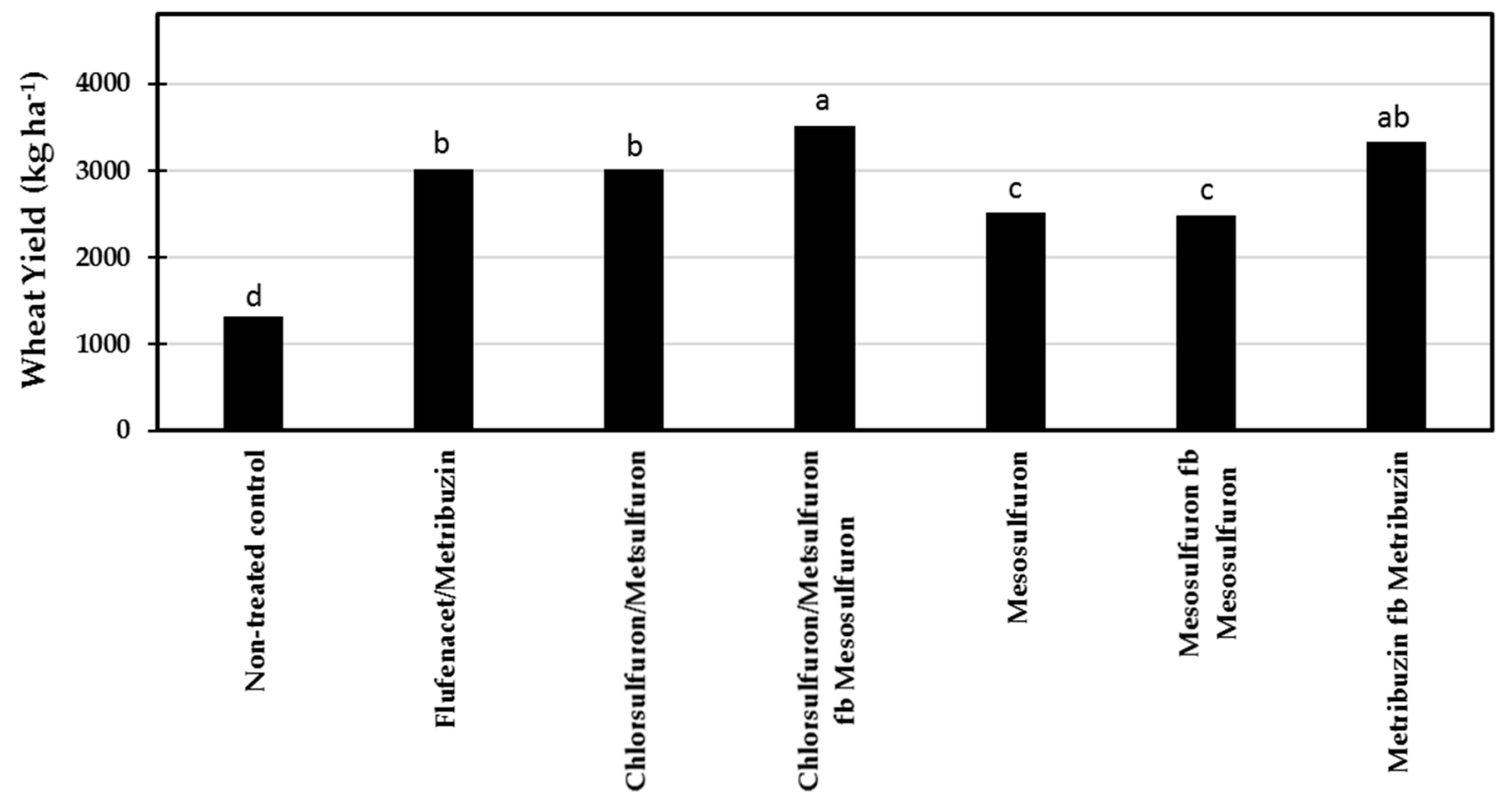

Figure 2. Wheat yield as affected by herbicide treatments in 2005-2006. Similar letter on bars indicates no statistical difference at $p \leq 0.05$. fb means followed by. 


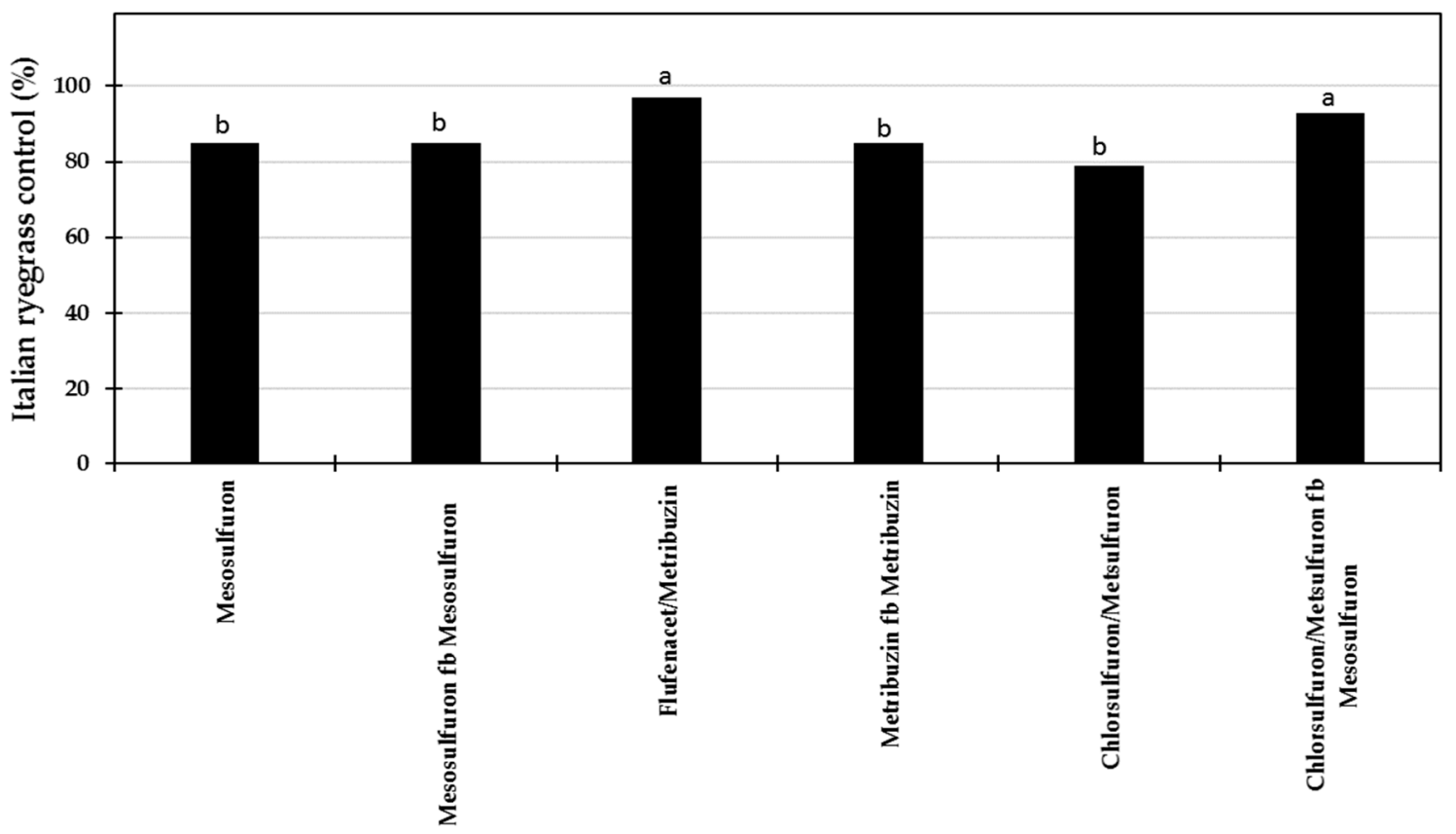

Figure 3. Italian ryegrass control as affected by the herbicide treatments in 2007. Similar letter on bars indicates no statistical difference at $p \leq 0.05$. fb means followed by.

\section{Discussion}

Across six years, flufenacet/metribuzin provided $87 \%$ or higher control of Italian ryegrass, which consequently increased wheat grain yields when compared to non-treated control. Flufenacet in the flufenacet/metribuzin herbicide mixture has residual herbicidal activity. Flufenacet inhibits the biosynthesis of very long chain fatty acids which are substrates for the formation of cuticular waxes and membrane phospholipids in plants [23]. Greater control of Italian ryegrass with flufenacet/metribuzin might have occurred due to its early application (1-2-leaf stage wheat) when weeds were small. Furthermore, the combination of these two modes of action ensures complete control of susceptible species and broadens the spectrum of control. The targets of these herbicides (metribuzin being a photosynthesis inhibitor) are enzymes in biochemical pathways that are critical for plant survival. Many studies have reported similar results with the use of flufenacet/metribuzin [12,16] for Italian ryegrass control. Ellis, Steckel, Main, De Melo, West and Mueller [16] reported 84 to $96 \%$ control of diclofop-resistant Italian ryegrass with flufenacet + metribuzin in Tennessee. Grey and Bridges [12] also reported $80 \%$ or higher control of Italian ryegrass with flufenacet plus metribuzin PRE at all rates including $0.304+0.76,0.344+0.86$, and $0.376+0.94 \mathrm{~kg} \mathrm{ha}^{-1}$. The performance of flufenacet plus metribuzin could vary widely, depending on environmental conditions. During the dry fall season, ryegrass control could be poor due to lack of herbicide activation. In Tennessee, flufenacet + metribuzin application at two- to three-leaf wheat stage resulted in 55\% and 97\% Italian ryegrass control in 1999 and 2000, respectively, which contributed to the highest wheat yield obtained compare to the other herbicide treatments used in their study [12].

Italian ryegrass control by metribuzin fb metribuzin ranged from $79 \%$ in 2007 to $94 \%$ in $2005-2006$. Metribuzin $\mathrm{fb}$ metribuzin effect on wheat yield also varied between years. About $82 \%$ control of Italian ryegrass from 2001 to 2004 did not increase wheat yield significantly relative to other herbicide treatments. Metribuzin has been reported to cause injury to wheat. Tolerance to metribuzin differs significantly among varieties. Grey and Bridges [12] reported that wheat yields were reduced because of injury to wheat by metribuzin, irrespective of application timing and rates.

Chlorsulfuron/metsulfuron mixture provided lower control $(<85 \%)$ in 2001 to 2004 and in 2007, but higher control (89\%) in 2005-2006. Bond, Stephenson IV, Barnes, Bararpour and Oliver [7] also 
reported $89 \%$ Italian ryegrass control $30 \mathrm{~d}$ after wheat emergence with chlorsulfuron/metsulfuron mixture applied PRE. Ryegrass control with this mixture increased to $>90 \%$ at $49 \mathrm{~d}$ after wheat emergence. Lower Italian ryegrass control results in greater competition with wheat plants and consequently, reduced wheat yield. Injury from chlorsulfuron/metsulfuron might also be responsible for lower wheat yields with this treatment. Grey and Bridges [12] reported 28\% and $10 \%$ wheat injury with chlorsulfuron/metsulfuron mixture at 54 and $151 \mathrm{~d}$ after planting, respectively, whereas less than $5 \%$ injury was reported by Bond, Stephenson IV, Barnes, Bararpour and Oliver [7]. Mesosulfuron application at 3-4 leaf stage ryegrass after PRE application of chlorsulfuron/metsulfuron increased Italian ryegrass control and wheat yield when compared to the application of chlorsulfuron/metsulfuron alone, due to the control of Italian ryegrass that emerged after the loss of residual activity of PRE application of chlorsulfuron/metsulfuron.

The addition of sprayable nitrogen $(\mathrm{N})$ and adjuvants often improves herbicide efficacy [24]. Mesosulfuron can be applied with MSO or with non-ionic surfactants + N fertilizer. In our study, the use of UAN (urea ammonium nitrate) with mesosulfuron only provided $65 \%$ control of Italian ryegrass. Grey et al. [24] reported that use of MSO and UAN with mesosulfuron provided maximum and most consistent Italian ryegrass control which indicated that a nitrogen additive is needed to increase uptake and translocation of mesosulfuron. In the same study, Italian ryegrass control varied from 44 to $97 \%$ when UAN was used with mesosulfuron due to unfavorable environmental conditions. The use of MSO with mesosulfuron in 2001 to 2004 increased Italian ryegrass control when compared to mesosulfuron alone, but it did not increase yield significantly. The MSO is a kind of fatty acid obtained from seed oil esterified with methyl alcohol [25]. Oil-based adjuvants enhance herbicide efficacy by spreading the spray droplets more on leaf surfaces and increasing herbicide penetration into the leaf cuticle [26]. The MSO can increase the wetted areas of droplets on both waxy and hairy leaves by decreasing the surface tension and contact angle $[27,28]$.

\section{Conclusions}

In Arkansas, diclofop-resistant Italian ryegrass is a major weed problem in wheat. The natural infestation of Arkansas diclofop-resistant Italian ryegrass interference reduced wheat yield an average of $70 \%$ over the 6 years. The use of MSO with mesosulfuron + UAN increased Italian ryegrass control compared to mesosulfuron + UAN alone. Mesosulfuron + MSO application after preemergence application of chlorsulfuron/metsulfuron improves Italian ryegrass control compared to chlorsulfuron/metsulfuron applied alone. This indicates that split application of different herbicides might be necessary to provide season-long control of Italian ryegrass. In Arkansas, USA, flufenacet/metribuzin (87-97\% control) at 1-2 leaf stage of wheat and chlorsulfuron/metsulfuron (PRE) followed by mesosulfuron at 3-4-leaf ryegrass (89-93\% control) are the most effective options for controlling diclofop-resistant Italian ryegrass in wheat.

Author Contributions: T.B. designed the experiments, collected data and did statistical analysis; T.B., R.R.H., G.K., J.A.B., N.R.B., T.P.T., T.H. Wilkerson and L.M.L. were involved with data interpretation, manuscript preparation, and editing.

Funding: This research received no external funding.

Conflicts of Interest: The authors declare no conflict of interest.

\section{References}

1. Shaner, D.L. Lessons learned from the history of herbicide resistance. Weed Sci. 2014, 62, 427-431. [CrossRef]

2. Heap, I. The International Survey of Herbicide Resistant Weeds. 2015. Available online: www.weedscience. com (accessed on 4 April 2018).

3. Bailey, W.A.; Wilson, H.P. Control of Italian ryegrass (Lolium multiflorum) in wheat (Triticum aestivum) with postemergence herbicides. Weed Technol. 2003, 17, 534-542. [CrossRef]

4. Webster, T. Weed survey-southern states. Proc. South. Weed Sci. Soc. 2002, 55, 237-254. 
5. Elmore, C.D. Weed survey: Southern states: Grass crops subsection. Proc. South. Weed Sci. Soc. 1988, 41, 395-410.

6. Bailey, W.A.; Hatzios, K.K.; Wilson, H.P. Responses of winter wheat and diclofop-methyl-sensitive and-resistant Italian ryegrass (Lolium multiflorum) to ae f130060 03. Weed Sci. 2003, 51, 515-522. [CrossRef]

7. Bond, J.A.; Stephenson IV, D.O.; Barnes, J.W.; Bararpour, M.T.; Oliver, L.R. Diclofop-resistant Italian ryegrass (Lolium multiflorum) control in imidazolinone-tolerant wheat. Weed Technol. 2005, 19, 437-442. [CrossRef]

8. Kuk, Y.-I.; Burgos, N.R.; Talbert, R.E. Cross-and multiple resistance of diclofop-resistant Lolium spp. Weed Sci. 2000, 48, 412-419. [CrossRef]

9. Stanger, C.E.; Appleby, A.P. Italian ryegrass (Lolium multiflorum) accessions tolerant to diclofop. Weed Sci. 1989, 37, 350-352.

10. Liebl, R.; Worsham, A.D. Interference of Italian ryegrass (Lolium multiflorum) in wheat (Triticum aestivum). Weed Sci. 1987, 35, 819-823.

11. Appleby, A.; Olson, P.; Colbert, D. Winter wheat yield reduction from interference by Italian ryegrass 1 . Agron. J. 1976, 68, 463-466. [CrossRef]

12. Grey, T.L.; Bridges, D.C. Alternatives to diclofop for the control of Italian ryegrass (Lolium multiflorum) in winter wheat (Triticum aestivum). Weed Technol. 2003, 17, 219-223. [CrossRef]

13. Senseman, S.A. Herbicide Handbook, 9th ed.; Weed Science Society of America: Lawrence, KS, USA, 2007.

14. Bararpour, T.R.; Oliver, L.; Franklin, H.; Lyons, I.V. Hoelon-resistant Italian ryegrass control with pinoxaden (axial). In Proceedings of the Arkansas Crop Protection Association Conference, Fayetteville, AR, USA, 1-2 December 2008; Volume 12, pp. 16-17.

15. Boeger, M.; Cederbaum, F.; Cornes, D.; Friedmann, A.; Glock, J.; Muehlebach, M.; Niderman, T. Milestones in the Discovery of Pinoxaden: A Unique Graminicide for Global Use in Cereal Crop; Axial Herbicide Release Publication; Syngenta Crop Protection AG: Basel, Switzerland, 2006.

16. Ellis, A.T.; Steckel, L.E.; Main, C.L.; De Melo, M.S.; West, D.R.; Mueller, T.C. A survey for diclofop-methyl resistance in Italian ryegrass from Tennessee and how to manage resistance in wheat. Weed Technol. 2010, 24, 303-309. [CrossRef]

17. Bailey, W.A.; Wilson, H.P.; Hines, T.E. Influence of ae f130060 03 application timing on Italian ryegrass (Lolium multiflorum) control. Weed Technol. 2003, 17, 842-853. [CrossRef]

18. Barnes, M.A.; Peeper, T.F.; Epplin, F.M.; Krenzer, E.G., Jr. Effects of herbicides on Italian ryegrass (Lolium multiflorum), forage production, and economic returns from dual-purpose winter wheat (Triticum aestivum). Weed Technol. 2001, 15, 264-270. [CrossRef]

19. Bond, J.A.; Eubank, T.W.; Bond, R.C.; Golden, B.R.; Edwards, H.M. Glyphosate-resistant Italian ryegrass (Lolium perenne ssp. multiflorum) control with fall-applied residual herbicides. Weed Technol. 2014, 28, 361-370.

20. Clemmer, K.C.; York, A.C.; Brownie, C. Italian ryegrass (Lolium multiflorum) control in imidazolinone-resistant wheat. Weed Technol. 2004, 18, 481-489. [CrossRef]

21. Bararpour, M.T.; Oliver, L.R. Comparison of wheat herbicides for control of diclofop-resistant Italian ryegrass. In Proceedings of the Arkansas Crop Protection Association Conference, Fayetteville, AR, USA, 26-27 November 2007; Volume 11, p. 1.

22. Fayetteville Monthly/Yearly Rainfall. Available online: https://www.weather.gov/tsa/climo_fyv_pcp_ monthv (accessed on 5 June 2018).

23. Senseman, S.A. Summary of Herbicide Mechanism of Action: Fatty Acid and Lipid Biosynthesis Inhibitors; Weed Science Society of America: Lawrence, KS, USA, 2007.

24. Grey, T.L.; Cutts III, G.S.; Sosnoskie, L.; Culpepper, A.S. Italian ryegrass (Lolium perenne) control and winter wheat response to post herbicides. Weed Technol. 2012, 26, 644-648. [CrossRef]

25. Miller, P.; Westra, P. Herbicide Surfactants, and Adjuvants; Crop Series; Production No. 0.559; Colorado State University Cooperative Extension: Fort Collins, CO, USA; Available online: https://erams.com/static/ wqtool/PDFs/bmps_colorado/00559.pdf (accessed on 20 June 2018).

26. Gauvrit, C.; Cabanne, F. Oils for weed control: Uses and mode of action. Pest Manag. Sci. 1993, 37, 147-153. [CrossRef] 
27. Xu, L.-Y.; Zhu, H.; Ozkan, H.; Bagley, W.E.; Derksen, R.C.; Krause, C.R. Adjuvant effects on evaporation time and wetted area of droplets on waxy leaves. Trans. ASABE 2010, 53, 13-20. [CrossRef]

28. Xu, L.; Zhu, H.; Ozkan, H.E.; Bagley, W.E.; Krause, C.R. Droplet evaporation and spread on waxy and hairy leaves associated with type and concentration of adjuvants. Pest Manag. Sci. 2011, 67, 842-851. [CrossRef] [PubMed] 